\title{
Oxidative Stress Biomarkers, Nut-Related Antioxidants, and Cardiovascular Disease
}

\author{
Julia Lorenzon dos Santos ${ }^{1}$, Alexandre Schaan de Quadros ${ }^{1}$, Camila Weschenfelder ${ }^{1}$, \\ Silvia Bueno Garofallo ${ }^{1}$ and Aline Marcadenti ${ }^{1,2, * \text { (D) }}$
}

1 Graduate Program in Health Sciences (Cardiology), Institute of Cardiology of Rio Grande do Sul/University Foundation of Cardiology (IC/FUC), Princesa Isabel Avenue, 395, Porto Alegre, 90040-371 Rio Grande do Sul, Brazil; julia.lorenzon@gmail.com (J.L.d.S.); consult.asq@gmail.com (A.S.d.Q.);

camilawesche@gmail.com (C.W.); silviagarofallo@hotmail.com (S.B.G.)

2 HCor Research Institute, Coracao Hospital (IP-HCor), Abílio Soares Street, 250, 04004-05 São Paulo, Brazil

* Correspondence: marcadenti.aline@gmail.com; Tel.: +55-(11)-3053-6611 (ext. 3558)

Received: 31 January 2020; Accepted: 2 March 2020; Published: 3 March 2020

check for updates

\begin{abstract}
Atherosclerosis is related to fat accumulation in the arterial walls and vascular stiffening, and results in acute coronary syndrome which is commonly associated with acute myocardial infarction. Oxidative stress participates in the pathogenesis of atherosclerosis. Thus, the inclusion of food sources of dietary antioxidants, such as different kinds of nuts, may improve biomarkers related to oxidative stress, contributing to a possible reduction in atherosclerosis progression. This article has briefly highlighted the interaction between oxidative stress, atherosclerosis, and cardiovascular disease, in addition to the effect of the consumption of different nuts and related dietary antioxidants-like polyphenols and vitamin E-on biomarkers of oxidative stress in primary and secondary cardiovascular prevention. Studies in vitro suggest that nuts may exert antioxidant effects by DNA repair mechanisms, lipid peroxidation prevention, modulation of the signaling pathways, and inhibition of the MAPK pathways through the suppression of NF- $\mathrm{B}$ and activation of the Nrf2 pathways. Studies conducted in animal models showed the ability of dietary nuts in improving biomarkers of oxidative stress, such as oxLDL and GPx. However, clinical trials in humans have not been conclusive, especially with regards to the secondary prevention of cardiovascular disease.
\end{abstract}

Keywords: oxidative stress; antioxidants; nuts; cardiovascular diseases

\section{Introduction}

Atherosclerosis, succinctly defined as arterial degeneration associated with increased fat accumulation in the arterial walls and an increased vascular stiffness [1], can result in acute coronary syndrome (ACS), a severe cardiac disorder that is commonly associated with acute myocardial infarction (AMI) [2,3]. AMI is the leading cause of fatality worldwide, responsible for more than nine million deaths yearly [4]. Oxidative stress participates in the pathogenesis of various diseases [5], including those of atherosclerotic origin. Damage caused to the deoxyribonucleic acid (DNA), ribonucleic acid (RNA), proteins, lipids, and the plasma membrane of the cell or the inner mitochondrial membrane and the nuclear envelope, are all implicated in an impaired circulatory and cardiac function [6,7]. In this sense, strategies that decrease the production of reactive oxygen species (ROS) should be used in the prevention and treatment of cardiovascular disease (CVD), including atherosclerosis and ACS [2,8].

Nutrients show antioxidant activities, especially vitamin E and phenolic compounds [9], with nuts standing out as a source of both [10]. In vitro studies [11-18], animal models [19-24], observational 
studies [25], and randomized trials [26-32] suggest the potential benefit of including different nuts in the diet to improve biomarkers of oxidative stress.

This article has briefly discussed the role of oxidative stress in the genesis of atherosclerosis and ACS, and has assessed studies that have evaluated the effect of dietary nut supplementation on oxidative stress parameters in the primary and secondary prevention of cardiovascular diseases.

\section{The Role of Oxidative Stress in the Development of Atherosclerosis and ACS}

Oxidative stress participates in the pathogenesis of atherosclerosis and its risk factors (namely, hypercholesterolemia, hypertension, and smoking) and increases free radical production in the vascular wall [33].

The resulting accumulation of DNA damage is associated with aging and age-related diseases, as it promotes apoptosis and cell senescence [33,34]. In addition, the vascular smooth muscle cells (VSMC), which play an important role in atherosclerosis development, are activated by DNA damage and replication and secrete high levels of senescence-associated secretory phenotype (SASP) factors with inflammatory characteristics, capable of promoting pro-atherosclerotic conditions $[34,35]$ in the adjacent cells.

Hypercholesterolemia is a major risk factor for atherosclerosis. An increase in the plasma cholesterol levels results in an endothelial dysfunction that facilitates the migration of lipids, especially that of the low-density lipoprotein cholesterol (LDL-c), into the arterial wall, where it is modified by ROS molecules, such as NADPH oxidase, xanthine oxidase, enzymes of the mitochondrial respiratory chain, and by the decoupling of the endothelial nitric oxide (NO) synthase. Endothelial cells and VSMC express adhesion molecules and chemotactically recruit the circulating monocytes which migrate to the subendothelial space where they are transformed into macrophages and then foamy macrophages by an LDL-c oxidization; the degree of oxidation correlates with the severity of the disease. This process results in a cascade of vascular changes that have clinical sequelae, including the narrowing of vessels, causing associated clinical symptoms (angina pectoris), and ACS of different types based on the stability of the atherosclerotic plaque [36-39]. ACS is a subcategory of coronary artery disease (CAD), which has characteristic symptoms and is often associated with AMI [2] (Figure 1).

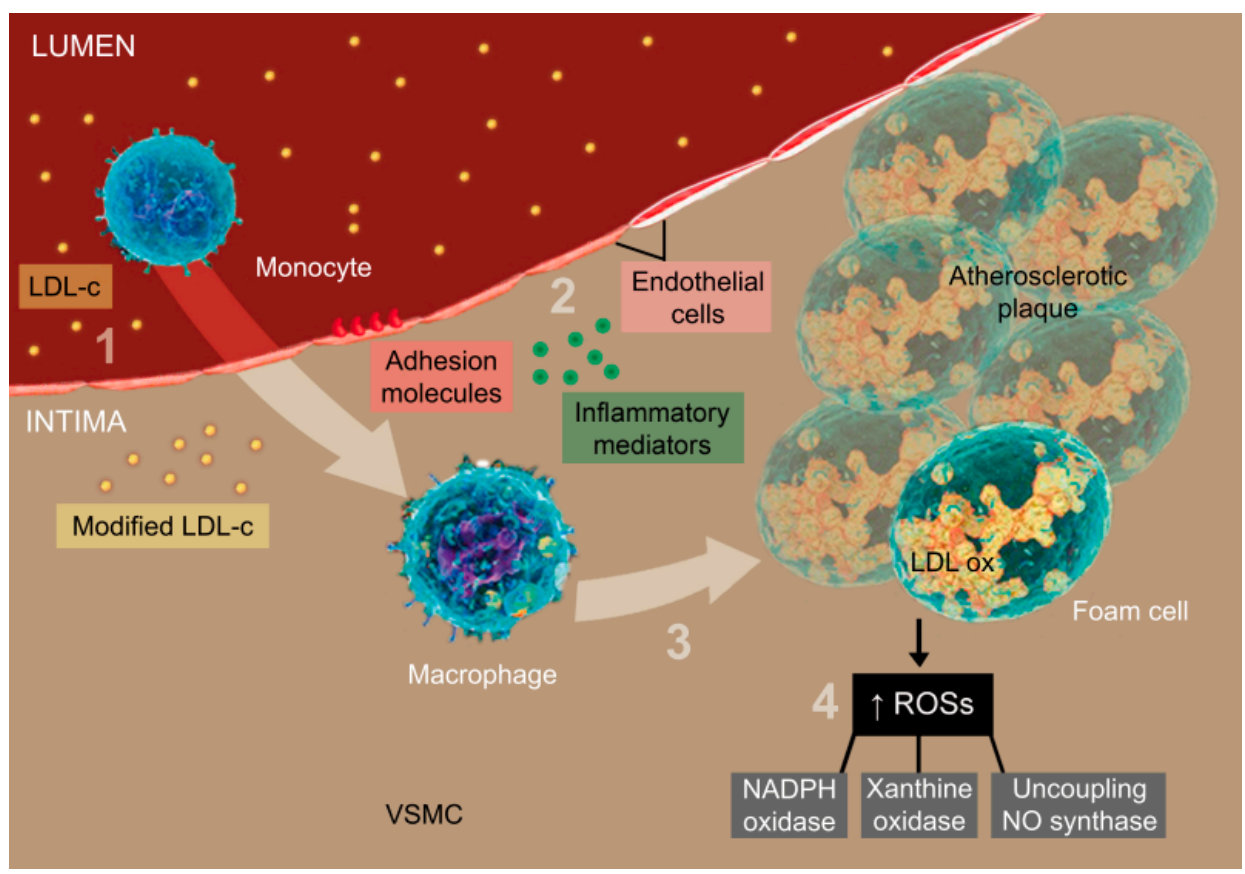

Figure 1. Representation of the atherosclerotic process adapted from Glaudemans et al. [40]. (1) Migration of LDL-c to the endothelial wall and its modification; (2) Uptake of the circulating 
monocytes by endothelial cells and VSMCs; (3) Transformation of monocytes into foamy macrophages from the uptake of LDL-c by scavenger receptors; (4) Increase of ROS and oxidation of LDL-c. Abbreviations: LDL-c: Low-density lipoprotein cholesterol; LDL ox: Oxidized LDL-c; VSMC: Vascular smooth muscle cells; ROS: Reactive oxygen species; NO: Nitric oxide.

In the context of atherosclerosis, some oxidative stress biomarkers and endogenous antioxidants have great clinical relevance, including the oxidized LDL-c (oxLDL), plasma total antioxidant capacity (TAC), superoxide dismutase (SOD), catalase, and glutathione (GHS). In addition, foods rich in exogenous antioxidants are closely related to having cardiovascular protective abilities.

\section{Nuts and Their Antioxidant Properties}

Nuts (tree nuts) and peanuts are rich sources of antioxidants, particularly vitamin E and polyphenols. In addition, other characteristics of these foods support recommending their dietary inclusion in CVD prevention and treatment.

\section{Definition and Nutritional Composition of Different Nuts}

Nuts are dry, thick fruits with thorny-covered seeds [41]. The best known are almonds, hazelnuts, Brazil nuts, cashews, macadamias, walnuts, pecans, and pistachios. Peanuts and Baru almonds are edible seeds classified as legumes, not nuts since their grains are produced in pods [41,42]. However, the characteristics and nutritional composition of peanuts are similar to those of nuts and they are considered as oleaginous fruits.

Nuts are composed of macronutrients $[43,44]$, containing high levels of proteins and unsaturated fats, in addition to dietary fiber [44], micronutrients [44], fat-soluble bioactives [44,45] which include polyunsaturated fatty acids (PUFA) and monounsaturated fatty acids (MUFA), and phytochemicals [46], such as phenolic compounds. These nutrients, in synergy, appear to be responsible for the beneficial effects of nuts on human health [46-52].

The lipid content of nuts, peanuts, and Baru almonds varies between $30 \%-60 \%$ of their approximate composition [52,53]. Regarding the fatty acid profile of these foods, high levels of oleic (C18:1) and linoleic (C18:2) [53] fatty acids are notable. Table 1 presents the fatty acid profile of the main nuts and edible seeds.

Phytochemicals are considered non-nutrient antioxidants [54] present in high concentrations in nuts which are considered a major dietary source of these antioxidants [55]. Phytochemicals present in nuts have bioactive properties, such as antioxidant, antiproliferative, anti-inflammatory, antiviral, and hypocholesterolemic properties [56]. However, the phytochemical content can vary considerably according to nut type, genotype, pre- and post-harvest conditions, and storage conditions [46]. Table 2 shows the phytochemical content of nuts and edible seeds.

Edible nuts and seeds are also sources of nutrient antioxidants, such as selenium, zinc, and vitamins A, C, E, with emphasis on tocopherols [54,57,58] (Table 3). However, their metabolic effects seem to be dependent on the bioaccessibility in the gastrointestinal tract, which may be influenced by dietary fiber and MUFA content of the nut [59]. 
Table 1. Fatty acid composition of nuts and edible seeds.

\begin{tabular}{|c|c|c|c|c|c|c|c|c|c|c|}
\hline \multirow{2}{*}{$\begin{array}{c}\text { Fatty Acids } \\
\text { (g/100g of Lipids) }\end{array}$} & \multicolumn{8}{|c|}{ Nuts } & \multicolumn{2}{|c|}{ Edible Seeds } \\
\hline & Almond & Hazelnut & Macadamia & Walnut & Pecan & Pistachio & Brazil Nut & Cashew Nut & Peanut & Baru Almond \\
\hline Saturated & 9.19 & 8.25 & 16.09 & 9.81 & 7.33 & 14.6 & 25.35 & 21.12 & 14.81 & 18.77 \\
\hline Palmitic C16:0 & 7.43 & 5.57 & 8.88 & 7.15 & 5.09 & 12.61 & 15.11 & 10.7 & 7.2 & 7.39 \\
\hline Stearic C18:0 & 1.7 & 2.5 & 4.26 & 2.55 & 2.02 & 1.42 & 9.51 & 9.33 & 1.84 & 4.62 \\
\hline Arachid C20:0 & 0.06 & 0.14 & 2.95 & 0.07 & 0.06 & 0.35 & 0.25 & 0.63 & 1.19 & 1.10 \\
\hline MUFA & 65.89 & 80.62 & 58.51 & 16.30 & 54.26 & 56.28 & 29.04 & 61.68 & 43.93 & 51.07 \\
\hline Palmitoleic C16:1 & 0.66 & 0.15 & 18.69 & 0.09 & 0.07 & 1.18 & 0.29 & 0.54 & 0.07 & - \\
\hline Oleic C18:1 & 65.89 & 80.52 & 58.51 & 16.14 & 53.65 & 55.98 & 28.75 & 61.15 & 42.48 & 48.37 \\
\hline Gadoleic C20:1 & 0.00 & 0.10 & 0.00 & 0.16 & 0.61 & 0.3 & - & - & 1.45 & 2.70 \\
\hline PUFA & 23.95 & 10.57 & 4.39 & 72.79 & 37.95 & 27.11 & 45.61 & 17.19 & 37.81 & 32.35 \\
\hline Linoleic C18:2 & 23.85 & 10.43 & 1.81 & 60.23 & 37 & 26.55 & 45.43 & 16.88 & 37.52 & 30.13 \\
\hline Linolenic C 18:3 & 0.10 & 0.14 & 2.58 & 12.56 & 0.95 & 0.56 & 0.18 & 0.32 & 0.29 & 2.22 \\
\hline
\end{tabular}

Abbreviations: MUFA: monounsaturated fatty acid; PUFA: polyunsaturated fatty acid. Adapted from Freitas and Naves, 2010 [52].

Table 2. Phytochemical content of nuts.

\begin{tabular}{|c|c|c|c|c|c|c|c|c|}
\hline \multirow{2}{*}{ Phytochemical } & \multicolumn{8}{|c|}{ Nuts } \\
\hline & Almond & Hazelnut & Macadamia & Walnut & Pecan & Pistachio & Brazil Nut & Cashew Nut \\
\hline Total phenolics (mg/100 g) & 261 & 447 & 233 & 1602 & 1588 & 703 & 197 & 242 \\
\hline Proanthocyanidins (mg/100 g) & 184.1 & 500.6 & 10 & 67.2 & 493.9 & 252.71 & 10 & 8.7 \\
\hline Flavonoids (mg/100 g) & 25.01 & 13.21 & 137.9 & 0.54 & 2713.49 & 136.45 & 0.85 & 1.12 \\
\hline $\begin{array}{l}\text { Phenolic acids and aldehydes } \\
\qquad(\mathrm{mg} / 100 \mathrm{~g})\end{array}$ & 0.44 & 1.87 & 3.69 & 39.11 & 2052 & 1.27 & 11.35 & - \\
\hline Carotenoids $(\mu \mathrm{g} / 100 \mathrm{~g})$ & 2 & 106 & - & 21 & 55 & 22832 & - & 31 \\
\hline Sterols $(\mathrm{mg} / 100 \mathrm{~g})$ & 192.37 & 132.47 & 105.7 & 197.89 & 233.52 & 189.43 & 160.19 & 154 \\
\hline
\end{tabular}


Table 3. Nutrient antioxidant concentration of different nuts and seeds per $100 \mathrm{~g}$.

\begin{tabular}{|c|c|c|c|c|c|c|c|c|c|}
\hline & Cashew Nut [60] & Brazil Nut $[57,60]$ & Almond [60] & Walnut $[60,61]$ & Pecan [60] & Pistachio [60] & Macadamia [60] & Hazelnut $[60,62]$ & Peanut $[60,63]$ \\
\hline Selenium $(\mu \mathrm{g})$ & 19.9 & 1917 & 4.1 & 4.9 & 3.8 & 7 & 3.6 & 2.4 & 9.3 \\
\hline Zinc (mg) & 5.78 & 4.06 & 3.12 & 3.09 & 4.53 & 2.2 & 1.3 & 2.45 & 2.77 \\
\hline Vitamin A $(\mu \mathrm{g})$ & 0 & 0 & 0 & 1 & 3 & 26 & 0 & 1 & 0 \\
\hline Vitamin C (mg) & 0.5 & 0.7 & 0 & 1.3 & 1.1 & 5.6 & 1.2 & 6.3 & 0 \\
\hline$\alpha$-tocopherol (mg) & 0.9 & 5.65 & 25.63 & 0.7 & 1.4 & 2.86 & 0.54 & 15.03 & 4.93 \\
\hline$\beta$-tocopherol (mg) & 0.03 & - & 0.23 & 0.10 & 0.39 & 0 & 0 & - & 0.33 \\
\hline$\gamma$-tocopherol (mg) & 5.31 & 116.2 & 0.64 & 22.65 & 24.44 & 1.67 & 0 & 1.36 & 10.4 \\
\hline
\end{tabular}




\section{Nuts, Antioxidants and Oxidative Stress: Studies In Vitro and in Animal Models}

\subsection{Studies In Vitro}

An in vitro study with plasma and platelets incubated in proanthocyanidin fraction from Medemia argun nuts $(0.5 \mu \mathrm{g} / \mathrm{mL}-50 \mu \mathrm{g} / \mathrm{mL})$, demonstrated a decrease in oxidation of the thiol and the carbonyl groups, and a significant increase in GSH, compared to that observed with peroxynitrite $\left(\mathrm{ONOO}^{-}\right)$ treatment only [11]. These polyphenols exert their antioxidant activity by DNA repair, lipid peroxidation prevention, modulation of the signaling pathways, and inhibition of the mitogen-activated protein kinases (MAPK) pathways through the suppression of nuclear factor kappa B (NF- $\mathrm{B}$ ) and activation of the nuclear factor erythroid 2-related factor 2 (Nrf2) pathways [12]. Oocytes of secondary follicles from lambs maintained for 18 days in control medium containing polyphenol resveratrol $(2 \mu \mathrm{M}$, $10 \mu \mathrm{M}$, or $30 \mu \mathrm{M}$ ) exhibited significant decreases in the intracellular GSH levels at $10 \mu \mathrm{M}$ and $30 \mu \mathrm{M}$ concentrations compared to $2 \mu \mathrm{M}$ due to a decreased mitochondrial activity [13].

Different nuts (almonds, macadamias, hazelnuts, pistachios, and walnuts) showed that their supernatant fractions displayed antioxidant effects after being fermented in vitro [14]. An investigation into the antioxidant effect of pistachios in the macrophage/monocyte cell line, J774, found that pretreatment with pistachio shells or roasted and salted pistachios in different concentrations decreased the production of ROS and malondialdehyde (MDA) significantly $(p<0.01)$ [15].

Walnut oil, in different concentrations $(40 \mu \mathrm{L} / \mathrm{mL}-319 \mu \mathrm{L} / \mathrm{mL})$ in U937 cells cultured for $24 \mathrm{~h}$ to $72 \mathrm{~h}$, had positive effects on SOD activity, with the greatest induction $(p \leq 0.01)$ seen within $48 \mathrm{~h}$ of incubation [16]. Additionally, defatted walnut flour exerted good antioxidant activity on the peroxide-injured nerve cells through the elimination of the hydroxyl radical and reduction of ROS in the selected peptides [17].

The effects of walnut extracts rich in polyphenols on human plasma in vitro was compared to ellagic acid, with a reduction in LDL-c oxidation of $87 \%$ and $38 \%$ observed, respectively; the copper-mediated LDL-c oxidation was inhibited by $84 \%$ in the presence of the extract (compared to $14 \%$ by ellagic acid) [18].

\subsection{Studies in Animal Models}

Male Wistar rats were divided into six groups [n: six per group: (1) control, (2) $75 \mathrm{mg}$ of Brazil nut (BN), (3) 150 mg BN, (4) ischemia-reperfusion (IR), (5) IR with 75 mg BN, and (6) IR with $150 \mathrm{mg}$ BN and submitted to BN daily seven days prior to surgery for IR, with animals sacrificed $48 \mathrm{~h}$ thereafter. Reduced oxidative stress-including elevated expression of inducible nitric oxide synthase (iNOS), nitrotyrosine renal expression, and plasma thiobarbituric acid reactive substances (TBARS), was observed in mice pretreated with BN (similar results with both doses) [19]. Male mice C57BL/6J fed either a common feed or fat-rich diet ( $45 \%$ or $21.5 \%$ energy from walnuts) for six weeks showed a decrease in MAPK changes and a reduction in lipid peroxidation [20]. Male mice fed with an atherogenic diet supplemented with mixed nuts (almonds, macadamias, peanuts, pistachios, cashews, Brazil nuts, and walnuts) or isolated pistachio showed significantly decreased concentrations of oxLDL as compared to that observed in the control knock-out mice $(p=0.044)$ [21]. Furthermore, apoE-deficient mice receiving supplementation (3\%) of mixed nuts (almonds, hazelnuts, and walnuts) showed significantly decreased levels of oxLDL $(p<0.05)$ compared to the group receiving an isocaloric diet supplemented with palm oil [22].

Male rats fed with a high-fat diet supplemented with pecan oil, polyphenol extract, or part or whole pieces of nuts for nine weeks showed a greater increase in antioxidant enzyme activity $(p<0.05)$, especially in the group supplemented with pecan oil [23]. Hyperlipidemic rats fed a fat-rich diet and pistachios for eight weeks showed a reduction of TBARS measured MDA $(p<0.01)$, and, although not significant, an increase in SOD compared to that observed in the control [24]. 


\section{Nuts and Oxidative Stress Biomarkers: Studies in Primary Cardiovascular Prevention}

The current consensus indicates that the inclusion of nuts in the diet helps in the prevention of primary CVD $[64,65]$. A review of major epidemiological studies, such as the Adventist Health Study [66], the Iowa Women's Health Study [67], the Nurses' Health Study [68], and the Physicians' Health Study [69] showed a 37\% lower risk for CVD in individuals who consumed nuts more than four times a week compared to those who rarely or never consumed nuts; moreover, a reduction in risk of $8.3 \%$ was assigned to each weekly portion of nuts [25].

The PREvención con DIeta MEDiterránea (PREDIMED) study [64] conducted in Spain enrolled 7447 individuals at high risk for CVD, who participated in one of three dietary interventions: The Mediterranean diet (MeDiet) supplemented with an extra-virgin olive oil (MeDiet + EVOO), the MeDiet supplemented with mixed nuts (MeDiet $+\mathrm{MN}$ ), and the control diet (low-fat standard as per the American Heart Association [AHA]). After a median follow-up of 4.8 years, there was a 30\% lower risk observed for AMI, stroke, and CVD-related mortality in the group allocated with the diet supplemented with extra-virgin olive oil, while there was a $28 \%$ reduced risk in the group supplemented with mixed nuts, compared to that in the control diet.

Subanalysis [70] of the PREDIMED study evaluated biomarkers related to oxidative stress, identifying greater SOD and catalase plasma activity ( $p<0.003$ and $p<0.004$, respectively) and less plasma xanthine oxidase activity $(p=0.008)$ in individuals undergoing interventions (the MeDiet + EVOO and the MeDiet $+\mathrm{MN}$ ). Another subanalysis [71] published by the same authors, detected an improvement in the plasma non-enzymatic antioxidant capacity (NEAC) levels after one year of intervention through increasing plasma levels of potential iron-reducing antioxidant (FRAP) in both interventions [the MeDiet + EVOO: $72.0 \mu \mathrm{mol} / \mathrm{L}$ (95\% CI, 34.2-109.9), and the MeDiet + MN: $48.9 \mu \mathrm{mol} / \mathrm{L}(24.3-73.5)]$.

Specifically regarding nuts, a study that evaluated the acute effect of consumption of four different forms of walnut [whole walnut (85 g), walnut oil (51 g), defatted walnut pulp (34 g), and walnut skin (5.6 g)] in overweight or obese individuals with moderate hypercholesterolemia, identified an increase in the antioxidant marker FRAP at all meals $(p<0.01)$, but this was less significant for defatted walnut pulp [72]. The nutritional intervention of one unit of Brazil nuts per day for three months in hemodialysis patients resulted in improved plasma glutathione peroxidase (GPx) levels and a reduction in the 8-hydroxy-2'-deoxyguanosine $(8-\mathrm{OHdG})$ and in the 8-isoprostane levels $(p<0.001)$ [73].

A placebo-controlled, parallel randomized clinical trial (RCT) [26] of 46 overweight and obese women, divided into two groups (normocaloric and isoenergetic diet + placebo [PLA] or normocaloric and isoenergetic diet $+20 \mathrm{~g}$ of Baru nuts [BARU]), found that after eight weeks of intervention, the BARU group showed a significant increase in the GPx activity in comparison to the PLA group (+0.08 U/mg, 95\% CI 0.05-0.12; vs. $-0.07 \mathrm{U} / \mathrm{mg}, 95 \%$ CI -0.12 to $-0.03, p<0.01$ ) accompanied by an increase in the plasma copper concentration $(p=0.037)$. However, no differences were observed in CAT, SOD activity or MDA concentration between groups. A further study [74] involving Baru nuts was divided into two periods of six weeks (four weeks of washing between periods) and conducted in 20 slightly hypercholesterolemic individuals. Participants were instructed to follow the supplementary diet of $20 \mathrm{~g} /$ day of Baru nuts or placebo, and at the end of the study, no changes were observed in the biomarkers of oxidative stress investigated.

Three RCTs were conducted involving dietary intervention with Brazil nuts, with some positive effects observed in all three. A double-blind, controlled, crossover trial [28] included 91 hypertensive and dyslipidemic patients, who received an individualized diet $+13 \mathrm{~g}$ granulated and defatted Brazil nuts (DBN) or individualized diet + placebo (IDP), found a $24 \%$ increase in the GPx3 activity $(112.66 \mathrm{nmol} / \mathrm{min} / \mathrm{mL} \pm 40.09 \mathrm{nmol} / \mathrm{min} / \mathrm{mL}$ to $128.32 \mathrm{nmol} / \mathrm{min} / \mathrm{mL} \pm 38.31 \mathrm{nmol} / \mathrm{min} / \mathrm{mL}, p<0.05)$ and $3.25 \%$ reduction in oxLDL $(66.31 \mathrm{U} / \mathrm{L} \pm 23.59 \mathrm{U} / \mathrm{L}$ to $60.68 \mathrm{U} / \mathrm{L} \pm 20.88 \mathrm{U} / \mathrm{L})$ in the DBN group at the end of 12 weeks. An inverse association between GPx3 and oxLDL was found, even after adjusting for sex, age, diabetes mellitus (DM) diagnosis, and body mass index (BMI) $(\beta-0.298, p=0.008)$. An increase in the GPx activity was also seen in the RCT [27] involving obese women who followed their usual 
diet and added one Brazil nut per day for two months when compared to the control (without any intervention) $(p=0.03)$. Obese adolescents, grouped to maintain their usual diets (control group) or a supplementary diet with $15 \mathrm{~g}-25 \mathrm{~g}$ of Brazil nuts per day (BNG group) for 16 weeks, showed a significant decrease in oxLDL in the BNG compared to the control group [BNG: 622.4 (457.2-665.0) to 514.9 (440.3-624.6); vs. control: 648.8 (515.9-737.9) to 646.9 (595-883.5); $p=0.02$ ] [31].

In a study conducted with type-2 DM (T2DM) patients [75], duration of eight weeks and intervention with cashew nuts, 50 individuals were allocated to two groups: those with adjusted calories, receiving $10 \%$ of the total energy value (TEV) in cashew nuts (CNG); and those who followed their usual diets. At the end of the study, there was a greater increase in the activity of paraoxonase 1 (PON-1) in the CNG, but without significance. In another study [76], children and adolescents with primary hyperlipidemia $(n=60)$ were randomly assigned to three groups: the hazelnut group with skin, the hazelnut group without skin, and the control group. The amount of hazelnut varied from $15 \mathrm{~g}-30 \mathrm{~g}$ in both interventions and all followed dietary guidelines. There were no significant changes in oxLDL.

Two RCTs [32,77] were conducted in patients with metabolic syndrome (MS) with the intervention of $30 \mathrm{~g} /$ day of mixed nuts (in different compositions). In one [77], 60 volunteers were included and distributed into two groups (nuts or control); the mixed nuts were composed of $15 \mathrm{~g}$ walnuts, $7.5 \mathrm{~g}$ pine nuts, and $7.5 \mathrm{~g}$ roasted peanuts, all following nutritional guidelines. No changes in the oxidative stress markers were identified after six weeks of intervention. In the other study [32], 50 patients, receiving a healthy diet prescription, were followed up for 12 weeks, after being divided into two groups (nuts or control); the mixed nuts were composed of $15 \mathrm{~g}$ walnuts, $7.5 \mathrm{~g}$ almonds, and $7.5 \mathrm{~g}$ hazelnuts; after intervention, urinary levels of the biomarker 8-oxo-dG were significantly reduced $(p<0.001)$ in the walnut group.

A study [29] with 60 individuals with MS, lasting 24 weeks, divided patients into two groups: the pistachio group (PG) and the control group (CG). All participants followed a specific diet and exercise program, with unsalted pistachios making up $20 \%$ of the TEV for the PG. At the end of the study, the PG showed a significant improvement in TBARS compared to that in the control $(p=0.01)$. Another study [30] involving almonds, recruited 20 patients with T2DM and mild hyperlipidemia and divided them into two groups: the almond group (AG) and the control group (CG). The AG received a calorie-adjusted diet with $20 \%$ of the TEV from unsalted roasted almonds, while the CG received a diet from the National Cholesterol Education Program (NCEP). After four weeks, AG showed a significant reduction in carbonyl protein and oxLDL $(28 \%, p=0.0003$ and $6.9 \%, p \leq 0.05$, respectively).

Studies previously described that evaluated the impact of different nuts on oxidative stress biomarkers in primary cardiovascular prevention are summarized in Table 4. 
Table 4. Randomized clinical trials on nuts and oxidative stress biomarkers in primary cardiovascular prevention.

\begin{tabular}{|c|c|c|c|c|c|c|c|c|c|}
\hline Author; Location & RCT Design & $\begin{array}{c}\text { Population } \\
\text { (n: Intervention/Control) }\end{array}$ & Type of Nut & Duration & Intervention & Control & Biomarkers & Main Results & Conclusion \\
\hline $\begin{array}{l}\text { de Souza } \\
\text { RGM et al. [26]; } \\
\text { Brazil }\end{array}$ & Placebo-controlled & $\begin{array}{l}\text { Women overweight and } \\
\text { obese }(n: 24 / 22)\end{array}$ & Baru nut & 8 weeks & $\begin{array}{l}\text { Normocaloric and } \\
\text { isocaloric diet-based } \\
\text { Guideline + 20g } \\
\text { Baru/day }\end{array}$ & $\begin{array}{l}\text { Normocaloric and } \\
\text { isocaloric diet-based } \\
\text { Guideline }\end{array}$ & $\begin{array}{l}\text { MDA, catalase, GPx, } \\
\text { SOD }\end{array}$ & $\begin{array}{c}\text { GPx intervention: }+0.08 ; \mathrm{GPx} \\
\text { control: }-0.07 . \\
p<0.01\end{array}$ & $\begin{array}{l}\text { Baru nut supplementation } \\
\text { increased GPx activity in women } \\
\text { with excess of weight. }\end{array}$ \\
\hline $\begin{array}{c}\text { GBS } \\
\text { Duarte et al. [27]; } \\
\text { Brazil }\end{array}$ & Controlled & Women obese (n: 36/36) & Brazil nut & 2 months & $\begin{array}{l}\text { Usual diet }+1 \text { unit } \\
\text { Brazil nut/day }\end{array}$ & Usual diet & GPx1 & $\begin{array}{l}\text { GPx1 intervention: } \Delta 8.5 ; \\
\text { GPx1 control: } \Delta 2.5 \\
p=0.03\end{array}$ & $\begin{array}{l}\text { Brazil nut supplementation } \\
\text { increased GPx1 activity in obese } \\
\text { women. }\end{array}$ \\
\hline $\begin{array}{l}\text { Darvish } \\
\text { Damavandi } \\
\text { Ret al. [75]; Iran }\end{array}$ & Controlled & $\begin{array}{l}\text { Individuals with T2DM } \\
(\mathrm{n}: 22 / 21)\end{array}$ & Cashew nut & 8 weeks & $\begin{array}{l}\text { Adjusted calorie diet } \\
\text { with 10\% of cashew and } \\
\text { reduced consumption } \\
\text { of visible fat }\end{array}$ & Usual diet & TAC and PON-1 & $\begin{array}{l}\text { Intervention vs control: TAC } \\
(p=0.34) ; \mathrm{PON}-1(p=0.41) .\end{array}$ & $\begin{array}{l}\text { Cashew nut did not improve } \\
\text { TAC and PON-1 plasma } \\
\text { activities in individuals with } \\
\text { T2DM. }\end{array}$ \\
\hline $\begin{array}{c}\text { Guaraldi } \\
\text { F et al. [76]; Italy }\end{array}$ & Controlled & $\begin{array}{l}\text { Children and adolescents } \\
\text { with hyperlipidemia } \\
\text { (n: 42/18) }\end{array}$ & $\begin{array}{l}\text { Hazelnut with or } \\
\text { without skin }\end{array}$ & 8 weeks & $\begin{array}{c}\text { Nutritional } \\
\text { recommendations } \\
\text { based on CHILD-1 }+ \\
\text { hazelnut with or out } \\
\text { skin } 15 \text { to } 30 \text { g/day }\end{array}$ & $\begin{array}{c}\text { Nutritional } \\
\text { recommendations } \\
\text { based on CHILD-1 }\end{array}$ & oxLDL & $\begin{array}{l}\text { oxLDL intervention vs control: } \\
\quad p=0.462 .\end{array}$ & $\begin{array}{l}\text { Hazelnuts did not improve the } \\
\text { oxLDL in children and } \\
\text { adolescents with } \\
\text { hyperlipidemia. }\end{array}$ \\
\hline $\begin{array}{l}\text { Huguenin } \\
\text { GV et al. [28]; Brazil }\end{array}$ & $\begin{array}{l}\text { Cross, double-blind, } \\
\text { placebo-controlled }\end{array}$ & $\begin{array}{l}\text { Individuals hypertension } \\
\text { and dyslipidemia (n: } 52 / 48 \text { ) }\end{array}$ & $\begin{array}{l}\text { Brazil nut partially } \\
\text { defatted }\end{array}$ & 12 weeks & $\begin{array}{c}\text { Nutritional counseling } \\
\text { for dyslipidemia and } \\
\text { hypertension + Brazil } \\
\text { nut 13g/day }\end{array}$ & $\begin{array}{l}\text { Nutritional counseling } \\
\text { for dyslipidemia and } \\
\text { hypertension }\end{array}$ & $\begin{array}{l}\text { GP×3, TAC, 8-epi } \\
\text { PGF2 } \alpha \text {, oxLDL }\end{array}$ & $\begin{array}{c}\text { GPx3 and oxLDL intervention: } \\
128.32 \pm 38.3160 .68 \pm 20.88, \\
\text { respectively. } \\
\text { GPx3 and oxLDL control: } \\
115.06 \pm 38.09 \text { and } 63.76 \pm 23.03 \\
\text { respectively. } \\
p<0.05\end{array}$ & $\begin{array}{c}\text { Brazil nut intake increased GPX3 } \\
\text { actitity and reduced oxLDL in } \\
\text { individuals with hypertension } \\
\text { and dyslipidemia. }\end{array}$ \\
\hline $\begin{array}{l}\text { Lee YJ et al. [77]; } \\
\text { South Korea }\end{array}$ & Controlled & $\begin{array}{l}\text { Individuals with MS } \\
\quad(\mathrm{n}: 30 / 30)\end{array}$ & $\begin{array}{l}\text { Mixed nuts (walnut, } \\
\text { peanuts, and pine } \\
\text { nuts) }\end{array}$ & 6 weeks & $\begin{array}{l}\text { Recommendations-based } \\
\text { dietary guidelines + } \\
\text { mix nuts } 30 \mathrm{~g} / \text { day }\end{array}$ & $\begin{array}{l}\text { Recommendations-based } \\
\text { dietary guidelines }\end{array}$ & MDA, oxLDL & $\begin{array}{l}\text { Serum and urine MDA and } \\
\text { oxLDL intervention } v \text { control: } \\
p=0.445, p=0.394, \text { and } p=0.885, \\
\text { respectively. }\end{array}$ & $\begin{array}{l}\text { Mixed nuts did not improve } \\
\text { MDA and oxLDL in individuals } \\
\text { with MS. }\end{array}$ \\
\hline $\begin{array}{l}\text { Bento AP et al. [74]; } \\
\text { Brazil }\end{array}$ & $\begin{array}{l}\text { Placebo-controlled, } \\
\text { crossover }\end{array}$ & $\begin{array}{c}\text { Mildly } \\
\text { hypercholesterolemic } \\
(\mathrm{n}: 20 / 20)\end{array}$ & Baru nut & 6 weeks & $\begin{array}{l}\text { Usual diet + Baru 20g } \\
\text { /day }\end{array}$ & Usual diet & TBARS, SOD, FRAP & $\begin{array}{c}\text { TBARS, SOD, FRAP intervention } \\
\text { vs control: } \\
p=0.82, p=0.34 \text {, and } p=0.33 \\
\text { respectively. }\end{array}$ & $\begin{array}{l}\text { Baru nuts did not improve } \\
\text { TBARS, SOD and FRAP in } \\
\text { mildly hypercholesterolemic } \\
\text { individuals. }\end{array}$ \\
\hline $\begin{array}{l}\text { Gulati } S \text { et al. [29]; } \\
\text { India }\end{array}$ & Controlled & $\begin{array}{c}\text { Asian Indian with MS } \\
(\mathrm{n}: 33 / 35)\end{array}$ & $\begin{array}{l}\text { Pistachio nut } \\
\text { unsalted }\end{array}$ & 24 weeks & $\begin{array}{l}\text { Guideline based on the } \\
\text { standard diet with } 20 \% \\
\text { of TEV in pistachio }\end{array}$ & $\begin{array}{l}\text { Guideline based on the } \\
\text { standard diet }\end{array}$ & TBARS & $\begin{array}{l}\text { TBARS intervention: } 2.4 \pm 1.3 ; \\
\text { TBARS control: } 3.1 \pm 1.3 \\
p=0.01\end{array}$ & $\begin{array}{l}\text { Pistachio nut improved plasma } \\
\text { TBARS in Asian Indian with MS }\end{array}$ \\
\hline $\begin{array}{l}\text { Liu JF et al. [30]; } \\
\text { Taiwan }\end{array}$ & Cross and controlled & $\begin{array}{l}\text { Individuals with T2DM } \\
\text { and mild hyperlipidemia } \\
\text { (n: 20/10) }\end{array}$ & Almond nut & 12 weeks & $\begin{array}{l}\text { Diet for obtaining or } \\
\text { maintaining weight } \\
\text { with } 20 \% \text { of TEV in } \\
\text { almond }\end{array}$ & $\begin{array}{l}\text { Diet for obtaining or } \\
\text { maintaining weight }\end{array}$ & $\begin{array}{l}\text { carbonyl protein, } \\
\text { oxLDL and MDA }\end{array}$ & $\begin{array}{c}\text { Carbonyl protein intervention: } \\
1.59 \pm 0.16 \text {; carbonyl protein } \\
\text { control: } 2.16 \pm 0.23 \text { ( } \mathrm{p}=0.0003) \\
\text { oxLDL: reduced } 6,9 \% \text { with } \\
\text { intervention as compared control. } \\
p \leq 0.05\end{array}$ & $\begin{array}{l}\text { Almond reduced plasma } \\
\text { carbonyl protein and oxLDL in } \\
\text { individuals with T2DM and mild } \\
\text { hyperlipidemia. }\end{array}$ \\
\hline $\begin{array}{c}\text { Maranhao } \\
\text { PA et al. [31]; Brazil }\end{array}$ & Controlled & Obese adolescents (n: 8/9) & Brazil nuts & 16 weeks & $\begin{array}{c}\text { Usual diet + Brazil nut } \\
15-25 \text { gdday }\end{array}$ & Usual diet & $\begin{array}{l}\text { GPx3, oxLDL, 8-epi } \\
\text { PGF2 } \alpha\end{array}$ & $\begin{array}{l}\text { oxLDL: reduced in intervention } \\
\text { group (622.4 to } 514.9) \text { ) } p=0.02\end{array}$ & $\begin{array}{l}\text { Brazil nuts improved oxLDL in } \\
\text { adolescents with obesity. }\end{array}$ \\
\hline $\begin{array}{l}\text { López-Uriarte } \\
\text { P et al. [32]; Spain }\end{array}$ & Controlled & $\begin{array}{l}\text { Individuals with MS } \\
\quad(\mathrm{n}: 25 / 25)\end{array}$ & $\begin{array}{l}\text { Mixed nuts (walnut, } \\
\text { almond and } \\
\text { hazelnut) }\end{array}$ & 12 weeks & $\begin{array}{l}\text { Nutritional guidelines + } \\
\text { mix nuts 30g/day }\end{array}$ & Nutritional guidelines & $\begin{array}{l}\text { plasma antioxidant } \\
\text { capacity, } \\
\text { oxLDL,8-oxo-dG, } \\
\text { 8-isoprostane }\end{array}$ & $\begin{array}{l}\text { Mean difference in final } \\
\text { 8-oxo-dG (intervention } v s \\
\text { control): } \Delta-2.42 ; p \leq 0.001\end{array}$ & $\begin{array}{l}\text { Mixed nuts improved urinary } \\
\text { 8-oxo-dG in individuals with } \\
\text { MS. }\end{array}$ \\
\hline
\end{tabular}

Abbreviations: RCT: Randomized clinical trial; MDA: Malondialdehyde; GPx: Glutathione peroxidase; SOD: Superoxide dismutase; GPx1: Glutathione peroxidase 1; GPx3: Glutathione

peroxidase 3; T2DM: Type-2 diabetes mellitus; TAC: Total antioxidant capacity; PON-1: Paraoxonase 1; 8-epi PGF2 $\alpha$ : 8-epi-prostaglandin F2 alpha; oxLDL: Oxidized LDL cholesterol; MS:

Metabolic syndrome; TBARS: Thiobarbituric acid reactive substances; FRAP: Ferric reducing antioxidant potential; 8-oxo-dG: 8-oxo-7,8-dihydro-2'-deoxyguanosine. 


\section{Nuts, Oxidative Stress Biomarkers, and Secondary Cardiovascular Prevention}

Regarding the oxidative stress biomarkers already mentioned, although evaluated in clinical trials conducted with individuals in primary prevention, there is little data available in the literature on the effect of supplementation of nuts and associated antioxidants in patients with documented CVD. The evaluation of such aspects in this population is more complex since such patients are usually on medications that can modulate inflammation and oxidative stress.

For example, a crossover RCT [78] evaluated the effect of consumption of $85 \mathrm{~g}$ of almonds per day in 45 patients with documented CAD with 22 weeks of follow-up. It was observed in the group receiving intervention of almond nuts, that there was a 103\% increase in the vitamin E intake, and a $10.3 \%$ increase in the serum levels of $\alpha$-tocopherol and $17.5 \%$ in the urinary levels of NO compared to those observed in the control group (the NCEP diet), despite the short follow-up period and lack of statistical power to evaluate oxidative stress biomarkers.

A non-RCT [79] evaluated the intake of nuts in secondary prevention in the context of the MeDiet, with patients receiving the MeDiet $(n=21)$ or diet of a low-fat type $(n=19)$. Forty men aged 45 years-65 years, with a history of coronary events for more than four months and less than two years and stable at the time of the study, with LDL-c $>190 \mathrm{mg} / \mathrm{dL}$, were followed for over three months. The recommendation for the MeDiet group was $10 \mathrm{~g}$ per day of nuts (Brazil nuts and/or almonds and/or walnuts). A reduction in the serum oxLDL in the low-fat diet group was observed, but the oxLDL:LDL-c ratio remained unchanged. This study also had a limited follow-up, beyond the inherent limitations of its design.

Additionally, there are studies in the literature that link oxidative stress and secondary cardiovascular prevention. For example, in the Cambridge Heart Antioxidant Study (CHAOS) study [80], nuts were not evaluated specifically, but there was supplementation with tocopherol-an important antioxidant present in nuts. This study randomized 2002 patients (mean age 61 years) with symptomatic CAD confirmed by angiography, to receive 400 IU-800 IU of daily vitamin E capsule, compared to that received by the placebo, followed up for approximately 510 days. There was a $47 \%$ reduction in the risk for non-fatal AMI, but no reduction in mortality.

In another study [81], the use of $\alpha$-tocopherol ( $50 \mathrm{mg} /$ day), $\beta$-carotene, or both, in 1862 male smokers with a history of AMI, with a follow-up of 5.3 years, was evaluated through an RCT. An increased relative risk of 1.58 (95\% CI 1.05-2.40) in cardiovascular-related death in the group that received $\beta$-carotene in combination with $\alpha$-tocopherol was observed, but there was no significant difference in the group receiving only supplementation with $\alpha$-tocopherol as compared to that received by the placebo.

Aligned with these findings, the GISSI (Gruppo Italiano per lo Studio della Sopravvivenza nell'Infarto miocardico)-Prevenzione study [82], a RCT that evaluated the effects of PUFA omega-3 supplementation ( $1 \mathrm{~g} /$ day, $n=2836)$, vitamin $\mathrm{E}(300 \mathrm{mg} /$ day, $n=2830)$, or both $(n=2830)$ in patients with a recent AMI ( $<3$ months), found no beneficial effect of $\alpha$-tocopherol supplementation on combined event of death, nonfatal MI, or stroke.

In order to clarify the conflicting results regarding vitamin E supplementation and secondary prevention, a Mendelian randomization study of two samples was conducted in 2019 to investigate the causal association between vitamin $\mathrm{E}$ and coronary heart disease (CHD). Three single nucleotide polymorphisms (SNP) were identified: rs964184, rs2108622, and rs11057830. The effect on CHD was assessed using vitamin E serum levels. Each $1 \mathrm{mg} / \mathrm{L}$ level increase was significantly associated with CAD among all participants [odds ratio (OR) 1.5, 95\% CI 1:03-1:06] [83].

These results suggest that nuts may increase the plasma $\alpha$-tocopherol and urinary NO levels even in polymedicated patients. However, the effects of vitamin E supplementation, not nut intake, on the outcomes in this population remain unclear. More robust data on the impact of nut consumption on oxidative stress markers and secondary cardiovascular prevention is needed. 


\section{Conclusions}

An increase in oxidative stress favors atherosclerotic progression and is positively associated with ACS. The intake of antioxidant food sources and/or antioxidant supplements seem to contribute to the prevention and treatment of diseases through already-known mechanisms; nuts are a good example of such food sources due to their favorable palatability and dose-effect that allow their inclusion in the majority of diets.

The effects of nut consumption on oxidative stress parameters in primary and secondary cardiovascular prevention are promising, but remain unclear, especially in secondary prevention. The variability of the results can be attributed to factors such as: concentration of antioxidants in the food studied, the dosage used, duration of the intervention, and the characteristics of the study population. In this context, further studies on the impact of the consumption of different nuts on oxidative stress biomarkers, with clinical relevance in both primary and secondary cardiovascular prevention, will be needed.

Author Contributions: J.L.d.S.; C.W.; S.B.G. wrote the manuscript, A.M. and A.S.d.Q. reviewed the manuscript. All authors have read and agreed to the published version of the manuscript.

Funding: The authors declare that they did not receive any grants to support this research work.

Conflicts of Interest: The authors declare that they have no conflicts of interest.

\section{References}

1. Aschoff, L. Introduction. In Arteriosclerosis: A Survey of Problem; Cowdry, E.V., Ed.; Macmillan: New York, NY, USA, 1933; pp. 1-18.

2. Lippi, G.; Sanchis-Gomar, F.; Cervellin, G. Chest pain, dyspnea and other symptoms in patients with type 1 and 2 myocardial infarction. A literature review. Int. J. Cardiol. 2016, 215, 20-22. [CrossRef]

3. Ambrose, J.; Singh, M. Pathophysiology of coronary artery disease leading to acute coronary syndromes. F1000Prime Rep. 2015, 7. [CrossRef]

4. World Health Organization (WHO). The Top 10 Causes of Death. Available online: https://www.who.int/ news-room/fact-sheets/detail/the-top-10-causes-of-death (accessed on 10 January 2020).

5. Liguori, I.; Russo, G.; Francesco, C.; Bulli, G.; Della-Morte, D.; Gargiulo, G.; Testa, G.; Cacciatore, F.; Bonaduce, D.; Abete, P. Oxidative stress, aging, and diseases. Clin. Interv. Aging 2018, 13, 757-772. [CrossRef]

6. Lefer, D.J.; Granger, D.N. Oxidative stress and cardiac disease. Am. J. Med. 2000, 109, 315-323. [CrossRef]

7. Barbosa, K.B.F.; Costa, N.M.B.; Alfenas, R.C.G.; Paula, S.O.; Minim, V.P.R.; Bressan, J. Estresse oxidativo: Conceito, implicações e fatores modulatórios. Rev. Nut. 2010, 23, 629-643. [CrossRef]

8. Kim, H.; Yun, J.; Kwon, S.M. Therapeutic Strategies for Oxidative Stress-Related Cardiovascular Diseases: Removal of Excess Reactive Oxygen Species in Adult Stem Cells. Oxidative Med. Cell. Longev. 2016, 2016, 1-11. [CrossRef] [PubMed]

9. Siti, H.N.; Kamisah, Y.; Kamsiah, J. The role of oxidative stress, antioxidants and vascular inflammation in cardiovascular disease (a review). Vascul. Pharmacol. 2015, 71, 40-56. [CrossRef] [PubMed]

10. Chaalal, M.; Ouchemoukh, S.; Mehenni, C.; Salhi, N.; Soufi, O.; Ydjedd, S.; Louaileche, H. Phenolic contents and in vitro antioxidant activity of four commonly consumed nuts in algeria. Acta Aliment. 2018, 48, 1-7. [CrossRef]

11. Morel, A.; Hamed, A.I.; Oleszek, W.; Stochmal, A.; Głowacki, R.; Olas, B. Protective action of proanthocyanidin fraction fromMedemia argunnuts against oxidative/nitrative damages of blood platelet and plasma components. Platelets 2014, 25, 75-80. [CrossRef]

12. Yang, L.; Xian, D.; Xiong, X.; Lai, R.; Song, J.; Zhong, J. Proanthocyanidins against Oxidative Stress: From Molecular Mechanisms to Clinical Applications. BioMed Res. Int. 2018, 85844136, 1-11. [CrossRef]

13. Macedo, T.J.S.; Barros, V.R.P.; Monte, A.P.O.; Gouveia, B.B.; Bezerra, M.É.S.; Cavalcante, A.Y.P.; Matos, M.H.T. Resveratrol has dose-dependent effects on DNA fragmentation and mitochondrial activity of ovine secondary follicles cultured in vitro. Zygote 2017, 25, 434-442. [CrossRef] [PubMed]

14. Lux, S.; Scharlau, D.; Schlörmann, W.; Birringer, M.; Glei, M. In vitro fermented nuts exhibit chemopreventive effects in HT29 colon cancer cells. Br. J. Nut. 2012, 108, 1177-1186. [CrossRef] [PubMed] 
15. Paterniti, I.; Impellizzeri, D.; Cordaro, M.; Siracusa, R.; Bisignano, C.; Gugliandolo, E.; Cuzzocrea, S. The Anti-Inflammatory and Antioxidant Potential of Pistachios (Pistacia vera L.) In Vitro and In Vivo. Nutrients 2017, 9, 915. [CrossRef] [PubMed]

16. Laubertová, L.; Koňariková, K.; Gbelcová, H.; Ďuračková, Z.; Žitňanová, I. Effect of walnut oil on hyperglycemia-induced oxidative stress and pro-inflammatory cytokines production. Eur. J. Nut. 2015, 54, 291-299. [CrossRef]

17. Sheng, J.; Yang, X.; Chen, J.; Peng, T.; Yin, X.; Liu, W.; Yang, X. Antioxidative effects and mechanism study of bioactive peptides from defatted walnut (Juglans regia L.) meal hydrolysate. J. Agric. Food Chem. 2019, 67, 3305-3312. [CrossRef]

18. Anderson, K.J.; Teuber, S.S.; Gobeille, A.; Cremin, P.; Waterhouse, A.L.; Steinberg, F.M. Walnut Polyphenolics Inhibit In Vitro Human Plasma and LDL Oxidation. J. Nutr. 2001, 131, 2837-2842. [CrossRef]

19. Anselmo, N.A.; Paskakulis, L.C.; Garcias, R.C.; Botelho, F.F.R.; Toledo, G.Q.; Cury, M.F.R. Prior intake of Brazil nuts attenuates renal injury induced by ischemia and reperfusion. Braz. J. Nephrol. 2018, 40, 10-17. [CrossRef]

20. Choi, Y.; Abdelmegeed, M.A.; Song, B.-J. Preventive effects of dietary walnuts on high-fat-induced hepatic fat accumulation, oxidative stress and apoptosis in mice. J. Nut. Biochem. 2016, 38, 70-80. [CrossRef]

21. Hong, M.; Groven, S.; Marx, A.; Rasmussen, C.; Beidler, J. Anti-Inflammatory, Antioxidant, and Hypolipidemic Effects of Mixed Nuts in Atherogenic Diet-Fed Rats. Molecules 2018, 23, 3126. [CrossRef]

22. Surra, J.C.; Barranquero, C.; Torcal, M.P.; Orman, I.; Segovia, J.C.; Guillén, N.; Navarro, M.A.; Arnal, C.; Osada, J. In comparison with pal oil, dietary nut supplementation delays the progression of atherosclerotic lesions in famale apoE-deficient mice. Br. J. Nutr. 2013, 109, 202-209. [CrossRef]

23. Avila, J.A.D.; Alvarez-Parrilla, E.; López-Díaz, J.A.; Maldonado-Mendoza, I.; Gómez-García, M.D.C.; De La Rosa, L.A. The pecan nut (Carya illinoinensis) and its oil and polyphenolic fractions differentially modulate lipid metabolism and the antioxidant enzyme activities in rats fed high-fat diets. Food Chem. 2015, 168, 529-537. [CrossRef] [PubMed]

24. Alturfan, A.A.; Emekeli-Alturfan, E.; Uslu, E. Consumption of pistachio nuts beneficially affect blood lipids and total antioxidant activity in rats fed a high-cholesterol diet. Folia Biol. (Praha) 2009, 55, 132-136. [PubMed]

25. Bitok, E.; Sabaté, J. Nuts and Cardiovascular Disease. Prog. Cardiovasc. Dis. 2018, 61, 33-37. [CrossRef] [PubMed]

26. De Souza, R.G.M.; Gomes, A.C.; Navarro, A.M.; Cunha, L.C.; da Silva, M.A.C.; Junior, F.B.; Mota, J.F. Baru Almonds Increase the Activity of Glutathione Peroxidase in Overweight and Obese Women: A Randomized, Placebo-Controlled Trial. Nutrients 2019, 11, 1750. [CrossRef] [PubMed]

27. Duarte, G.B.S.; Reis, B.Z.; Rogero, M.M.; Vargas-Mendez, E.; Barbosa, F.; Cercato, C.; Cozzolino, S.M.F. Consumption of Brazil nuts with high selenium levels increased inflammation biomarkers in obese women: A randomized controlled trial. Nutrition 2019, 63, 162-168. [CrossRef] [PubMed]

28. Huguenin, G.V.; Oliveira, G.M.M.; Moreira, A.S.B.; Saint'Pierre, T.D.; Gonçalves, R.A.; Pinheiro-Mulder, A.R.; Rosa, G. Improvement of antioxidant status after Brazil nut intake in hypertensive and dyslipidemic subjects. Nutr. J. 2015, 14, 1-10. [CrossRef]

29. Gulati, S.; Misra, A.; Pandey, R.M.; Bhatt, S.P.; Saluja, S. Effects of pistachio nuts on body composition, metabolic, inflammatory and oxidative stress parameters in Asian Indians with metabolic syndrome: A 24-wk, randomized control trial. Nutrition 2015, 30, 192-197. [CrossRef]

30. Liu, J.F.; Liu, Y.-H.; Chen, C.-M.; Chang, W.-H.; Chen, C.-Y.O. The effect of almonds on inflammation and oxidative stress in Chinese patients with type 2 diabetes mellitus: A randomized crossover controlled feeding trial. Eur. J. Nut. 2012, 52, 927-935. [CrossRef]

31. Maranhão, P.A.; Kraemer-Aguiar, L.G.; de Oliveira, C.L.; Kuschnir, M.C.; Vieira, Y.R.; Souza, M.G.; Bouskela, E. Brazil nuts intake improves lipid profile, oxidative stress and microvascular function in obese adolescents: A randomized controlled trial. Nutr. Metab. 2011, 8, 1-8. [CrossRef]

32. López-Uriarte, P.; Nogués, R.; Saez, G.; Bulló, M.; Romeu, M.; Masana, L.; Salas-Salvadó, J. Effect of nut consumption on oxidative stress and the endothelial function in metabolic syndrome. Clin. Nutr. 2010, 29, 373-380. [CrossRef]

33. Campisi, J. Senescent cells, tumor suppression, and organismal aging: Good citizens, bad neighbors. Cell 2005, 120, 513-522. [CrossRef] [PubMed] 
34. Gardner, S.E.; Humphry, M.; Bennett, M.R.; Clarke, M.C. Senescent vascular smooth muscle cells drive inflammation through an interleukin- $\alpha$-dependent senescence-associated secretory phenotype. Arterioscler. Thromb. Vasc. Biol. 2015, 35, 1963-1974. [CrossRef] [PubMed]

35. Acosta, J.C.; Banito, A.; Wuestefeld, T.; Georgilis, A.; Janich, P.; Morton, J.P.; Athineos, D.; Kang, T.W.; Lasitschka, F.; Andrulis, M.; et al. A complex secretory program orchestrated by the inflammasome controls paracrine senescence. Nat. Cell Biol. 2013, 15, 978-990. [CrossRef] [PubMed]

36. Li, H.; Horke, S.; Förstermann, U. Vascular oxidative stress, nitric oxide and atherosclerosis. Atherosclerosis 2014, 237, 208-219. [CrossRef]

37. Sakakura, K.; Nakano, M.; Otsuka, F.; Ladich, E.; Kolodgie, F.D.; Virmani, R. Pathophysiology of atherosclerosis plaque progression. Heart Lung Circ. 2013, 22, 399-411. [CrossRef]

38. Förstermann, U. Oxidative stress in vascular disease: Causes, defense mechanisms and potential therapies. Nat. Clin. Pract. Cardiovasc. Med. 2008, 5, 338-349. [CrossRef]

39. Förstermann, U. Nitric oxide and oxidative stress in vascular disease. Pflügers Arch.-Eur. J. Physiol. 2010, 459, 923-939. [CrossRef]

40. Glaudemans, A.W.J.M.; Slart, R.H.J.A.; Bozzao, A.; Bonanno, E.; Arca, M.; Dierckx, R.A.J.O.; Signore, A. Molecular imaging in atherosclerosis. Eur. J. Nucl. Med. Mol. Imaging 2010, 37, 2381-2397. [CrossRef]

41. Judd, W.S.; Campbell, C.S.; Kellogg, E.A.; Stevens, P.F.; Donoghue, M.J. Taxonomic evidence: Structural and biochemical characters. In Plant Systematics: A Phylogentetic Approach, 2nd ed.; Judd, W.S., Campbell, C.S., Kellogg, E.A., Stevens, P.F., Donoghue, M.J., Eds.; Massachusetts: Sunderland, UK, 2002; pp. 55-104.

42. Freitas, J.; Fernandes, D.; Czeder, L.; Lima, J.; Sousa, A.; Naves, M. Edible Seeds and Nuts Grown in Brazil as Sources of Protein for Human Nutrition. Food Nutr. Sci. 2012, 3, 857-862. [CrossRef]

43. Venkatachalam, M.; Sathe, S.K. Chemical composition of selected edible nut seeds. J. Agric. Food Chem. 2006, 54, 4705-4714. [CrossRef]

44. US Department of Agriculture. USDA National Nutrition Database for Standard Reference; Release 26; USDA: Springfield, VA, USA, 2013.

45. Miraliakbari, H.; Shahidi, F. Lipid class compositions, tocopherols and sterols of tree nut oils extracted with different solvents. J. Food Lipids 2008, 15, 81-96. [CrossRef]

46. Bolling, B.W.; Chen, C.Y.; McKay, D.L.; Blumberg, J.B. Tree nut phytochemicals: Composition, antioxidant capacity, bioactivity, impact factors: A systematic review of almonds, Brazils, cashews, hazelnuts, macadamias, pecans, pine nuts, pistachios and walnuts. Nutr. Res. Rev. 2011, 24, 244-275. [CrossRef] [PubMed]

47. Alasalvar, C.; Bolling, B.W. Review of nut phytochemicals, fat-soluble bioactives, antioxidant components and health effects. Br. J. Nutr. 2015, 113, 68-78. [CrossRef] [PubMed]

48. Cardoso, B.R.; Duarte, G.B.S.; Reis, B.Z.; Cozzolino, S.M.F. Brazil nuts: Nutritional composition, health benefits and safety aspects. Food Res Int. 2017, 100, 9-18. [CrossRef]

49. De Souza, R.G.M.; Schincaglia, R.M.; Pimentel, G.D.; Mota, J.F. Nuts and Human Health Outcomes: A Systematic Review. Nutrients 2017, 9, 1311. [CrossRef]

50. Sánchez-González, C.; Ciudad, C.J.; Noé, V.; Izquierdo-Pulido, M. Health benefits of walnut polyphenols: An exploration beyond their lipid profile. Crit. Rev. Food Sci. Nutr. 2017, 57, 3373-3383. [CrossRef]

51. Kim, Y.; Keogh, J.B.; Clifton, P.M. Benefits of Nut Consumption on Insulin Resistance and Cardiovascular Risk Factors: Multiple Potential Mechanisms of Actions. Nutrients 2017, 9, 1271. [CrossRef]

52. Freitas, J.B.; Naves, M.M.V. Chemical composition of nuts and edible seeds and their relation to nutrition and health. Rev. Nutr. 2010, 23, 269-279. [CrossRef]

53. Vera, R.; Soares Junior, M.S.; Naves, R.V.; Souza, E.R.B.; Fernandes, E.P.; Caliari, M.; Leandro, W.M. Características químicas de amêndoas de barueiros (dipteryx alata vog.) de ocorrência natural no cerrado do estado de Goiás, Brasil. Rev. Bras. Frutic. 2009, 31, 112-118. [CrossRef]

54. Alasalvar, C.; Shahidi, F. Natural antioxidants in tree nuts. Eur. J. Lipid Technol. 2009, 111, $1056-1062$. [CrossRef]

55. Pérez-Jiménez, J.; Neveu, V.; Vos, F.; Scalbert, A. Identification of the 100 richest dietary sources of polyphenols: An application of the Phenol-Explorer database. Eur. J. Clin. Nutr. 2010, 64, S112-S120. [CrossRef] [PubMed]

56. Bolling, B.W.; McKay, D.L.; Blumberg, J.B. The phytochemical composition and antioxidant actions of tree nuts. Asia Pac. J. Clin. Nutr. 2010, 19, 117-123. [PubMed] 
57. Ryan, E.; Galvin, K.; O'Connor, T.P.; Maguire, A.R.; O’Brien, N.M. Fatty acid profile, tocopherol, squalene and phytosterol content of brazil, pecan, pine, pistachio and cashew nuts. Int. J. Food Sci. Nutr. 2006, 54, 219-228. [CrossRef] [PubMed]

58. Dugo, G.; La Pera, L.; Lo Turco, V.; Mavrogeni, E.; Alfa, M. Determination of selenium in nuts by cathodictripping potentiometry (CSP). J. Agric. Food Chem. 2003, 51, 3722-3725. [CrossRef] [PubMed]

59. Stevens-Barrón, J.C.; de la Rosa, L.A.; Wall-Medrano, A.; Álvarez-Parrilla, E.; Rodríguez-Ramirez, R.; Robles-Zepeda, R.E.; Astiazaran-García, H. Chemical Composition and In Vitro Bioaccessibility of Antioxidant Phytochemicals from Selected Edible Nuts. Nutrients 2019, 11, 2303. [CrossRef]

60. USDA-United States Department of Agriculture. Available online: https://fdc.nal.usda.gov/ (accessed on 31 December 2019).

61. Amaral, J.S.; Alves, M.R.; Seabra, R.M.; Oliveira, B.P.P. Vitamin E compositions of walnuts (Juglans regia L.): A 3-year comparative study of different cultivars. J. Agric. Food Chem. 2005, 53, 5467-5472. [CrossRef] [PubMed]

62. Köksal, A.I.; Artik, N.A.; Şimşek, A.; Güne, N. Nutrient composition of hazelnut (Corylus avellana L.) varieties cultivated in Turkey. Food Chem. 2006, 99, 509-515. [CrossRef]

63. Shin, E.C.; Huang, Y.Z.; Pegg, R.B.; Phillips, R.D.; Eitenmiller, R.R. Commercial runner peanut cultivars in the United States: Tocopherol composition. J. Agric. Food Chem. 2009, 57, 10289-10295. [CrossRef]

64. Estruch, R.; Ros, E.; Salas-Salvadó, J.; Covas, M.I.; Corella, D.; Arós, F.; Gómez-Gracia, E.; Ruiz-Gutiérrez, V.; Fiol, M.; Lapetra, J.; et al. Primary Prevention of Cardiovascular Disease with a Mediterranean Diet Supplemented with Extra-Virgin Olive Oil or Nuts. N. Engl. J. Med. 2018, 378, e34. [CrossRef]

65. Arnett, D.K.; Blumenthal, R.S.; Albert, M.A.; Buroker, A.B.; Goldberger, Z.D.; Hahn, E.J.; Himmelfarb, C.D.; Khera, A.; Lloyd-Jones, D.; McEvoy, J.W.; et al. 2019 ACC/AHA Guideline on the Primary Prevention of Cardiovascular Disease: A Report of the American College of Cardiology/American Heart Association Task Force on Clinical Practice Guidelines. Circulation 2019, 140, e596-e646.

66. Fraser, G.E.; Sabaté, J.; Beeson, W.L.; Strahan, T.M. A possible protective effect of nut consumption on risk of coronary heart disease. The Adventist Health Study. Arch. Intern. Med. 1992, 152, 1416-1424. [CrossRef] [PubMed]

67. Ellsworth, J.L.; Kushi, L.H.; Folsom, A.R. Frequent nut intake and risk of death from coronary heart disease and all causes in postmenopausal women: The Iowa Women's Health Study. Nutr. Metab. Cardiovasc. Dis. 2001, 11, 372-377. [PubMed]

68. Bao, Y. Association of nut consumption with total and cause-specific mortality. Indian Heart J. 2014, 66, 388-389. [CrossRef]

69. Hshieh, T.T.; Petrone, A.B.; Djoussé, L. Nut consupmtion and risk of mortality in the Physicians Health Study. Am. J. Clin. Nutr. 2015, 101, 407-412. [CrossRef] [PubMed]

70. Sureda, A.; Bibiloni, M.D.; Martorell, M.; Buil-Cosiales, P.; Marti, A.; Pons, A.; Tur, J.A.; Martinez-Gonzalez, M.Á.; PREDIMED Study Investigators. Mediterranean diets supplemented with virgin olive oil and nuts enhance plasmatic antioxidant capabilities and decrease xanthine oxidase activity in people with metabolic syndrome: The PREDIMED study. Mol. Nutr. Food Res. 2016, 60, 2654-2664. [CrossRef] [PubMed]

71. Zamora-Ros, R.; Serafini,M.; Estruch, R.; Lamuela-Raventós, R.M.; Martínez-González, M.A.; Salas-Salvadó, J.; Andres-Lacueva, C. Mediterranean diet and non enzymatic antioxidant capacity in the PREDIMED study: Evidence for a mechanism of antioxidant tuning. Nutr. Metab. Cardiovasc. Dis. 2013, 23, 1167-1174. [CrossRef]

72. Berryman, C.E.; Grieger, J.A.; West, S.G.; Chen, C.-Y.O.; Blumberg, J.B.; Rothblat, G.H.; Kris-Etherton, P.M. Acute Consumption of Walnuts and Walnut Components Differentially Affect Postprandial Lipemia, Endothelial Function, Oxidative Stress, and Cholesterol Efflux in Humans with Mild Hypercholesterolemia. J. Nutr. 2013, 143, 788-794. [CrossRef]

73. Stockler-Pinto, M.B.; Mafra, D.; Moraes, C.; Lobo, J.; Boaventura, G.T.; Farage, N.E.; Malm, O. Brazil Nut (Bertholletia excelsa, H.B.K.) Improves Oxidative Stress and Inflammation Biomarkers in Hemodialysis Patients. Biol. Trace Elem. Res. 2014, 158, 105-112.

74. Bento, A.P.N.; Cominetti, C.; Simões Filho, A.; Naves, M.M.V. Baru almond improves lipid profile in mildly hypercholesterolemic subjects: A randomized, controlled, crossover study. Nutr. Metab. Cardiovasc. Dis. 2014, 24, 1330-1336. [CrossRef] 
75. Darvish, D.R.; Mousavi, S.N.; Shidfar, F.; Mohammadi, V.; Rajab, A. Effects of Daily Consumption of Cashews on Oxidative Stress and Atherogenic Indices in Patients with Type 2 Diabetes: A Randomized, Controlled-Feeding Trial. Int. J. Endocrinol. Metab. 2019, 17, e70744.

76. Guaraldi, F.; Deon, V.; Del Bo', C.; Vendrame, S.; Porrini, M.; Riso, P.; Guardamagna, O. Effect of short-term hazelnut consumption on DNA damage and oxidized LDL in children and adolescents with primary hyperlipidemia: A randomized controlled trial. J. Nutr. Biochem. 2018, 57, 206-211. [CrossRef] [PubMed]

77. Lee, Y.J.; Nam, G.E.; Seo, J.A.; Yoon, T.; Seo, I.; Lee, J.H.; Kim, N.H. Nut consumption has favorable effects on lipid profiles of Korean women with metabolic syndrome. Nutr. Res. 2014, 34, 814-820. [CrossRef] [PubMed]

78. Chen, C.Y.; Holbrook, M.; Duess, M.A.; Dohadwala, M.M.; Hamburg, N.M.; Asztalos, B.F.; Milbury, P.E.; Blumberg, J.B.; Vita, J.A. Effect of almond consumption on vascular function in patients with coronary artery disease: A randomized, controlled, cross-over trial. Nutr. J. 2015, 17, 61. [CrossRef] [PubMed]

79. Thomazella, M.C.; Góes, M.F.; Andrade, C.R.; Debbas, V.; Barbeiro, D.F.; Correia, R.L.; Marie, S.K.; Cardounel, A.J.; daLuz, P.L.; Laurindo, F.R. Effects of high adherence to mediterranean or low-fat diets in medicated secondary prevention patients. Am. J. Cardiol. 2011, 108, 1523-1529. [CrossRef] [PubMed]

80. Stephens, N.G.; Parsons, A.; Schofield, P.M.; Kelly, F.; Cheeseman, K.; Mitchinson, M.J. Randomised controlled trial of vitamina $\mathrm{E}$ in patients with coronary disease: Cambridge Heart Antioxidant Study (CHAOS). Lancet 1996, 23, 781-786. [CrossRef]

81. Rapola, J.M.; Virtamo, J.; Ripatti, S.; Huttunen, J.K.; Albanes, D.; Taylor, P.R.; Heinonen, O.P. Randomised trial of alpha-tocopherol and beta-carotene supplements on incidence of major coronary events in men with previous myocardial infarction. Lancet 1997, 349, 1715-1720. [CrossRef]

82. GISSI-Prevenzione Investigators. Dietary supplementation with n-3 polyunsaturated fatty acids and vitamin E after myocardial infarction: Results of the GISSI-Prevenzione trial. Gruppo Italiano per lo Studio della Sopravvivenza nell'Infarto miocardico. Lancet 1999, 354, 447-455.

83. Wang, T.; Lin, X. Circulating Vitamina E Levels and Risk of Coronary Artery Disease and Myocardial Infarction: A Mendelian Randomization Study. Nutrients 2019, 11, 2153. [CrossRef]

(C) 2020 by the authors. Licensee MDPI, Basel, Switzerland. This article is an open access article distributed under the terms and conditions of the Creative Commons Attribution (CC BY) license (http://creativecommons.org/licenses/by/4.0/). 